\title{
New collider gets the nod
}

BRITISH high-energy physicists were hardly able to believe their luck last week. The ruling council of the European Organization for Nuclear Research (CERN) at Geneva approved an upgrading of its protonantiproton collider that will cost SF55 million ( $£ 18$ million) despite the insistence of Britain that it could not provide its share of what amounts to a loan to CERN to cover the cost of the project. British scientists are therefore looking forward to using significantly improved facilities at no extra expense.

The decision taken last week was to upgrade the antiproton beam by building an antiproton collector, ACOL, to supplement the existing antiproton accumulator. The collector, which fits in an existing building, will accept and stochastically cool antiprotons with a wider angle and momentum range than the existing accumulator, thus increasing intensity. A new lithium lens downstream of the metallic target that produces the antiprotons is also planned. The upgrading will lead to at least a 10-fold increase in luminosity (events per second) and a modest increase in energy, from $270 / 270$ $\mathrm{GeV}$ to $310 / 310 \mathrm{GeV}$. The improvements will ensure that the collider, which generated much excitement earlier this year for producing the first evidence of $Z^{0}$ and W bosons, stays competitive for an extra 3 or 4 years, well into the 1990s.

The problem facing last week's council meeting was that CERN's budget is already fully committed. The suggestion made was that member states might temporarily forgo about one half of a special rebate that has become payable this year with the accession to the organization of Spain. The rebate would instead be made upon the completion of LEP, CERN's electronpositron collider now under construction. According to CERN's rules, late joiners have to make "special contributions" in addition to their normal subscriptions, in order to compensate existing members for capital they have already invested. ACOL, it was argued, could be built with part of Spain's "special contribution".

Britain, however, was adamant that, because of domestic financial pressure on the Science and Engineering Research Council, it would not be able to accept any postponement of the rebate. Other major contributors (France, West Germany, Italy) were able to be more flexible, perhaps because, by CERN's budget rules, their contributions (unlike Britain's) are set to decrease in future years owing to their relatively poor economic performance against the Swiss franc.

According to Dr John Walsh of the British Science and Engineering Research Council, who was a member of the UK delegation, other countries are unlikely to want to enforce restrictions on British scientists using the upgraded collider, which is the only one of its type in the world and will remain so until the Fermilab Tevatron comes on stream later this decade. Financial details of the ACOL package will be settled at a meeting of CERN's financial committee in February.

Tim Beardsley

\section{UK science budget The pie is sliced}

SIR Keith Joseph, Secretary of State for Education and Science in the British Government, las week gave notice of how the $£ 549$ million his department intends to spend directly on scientific research next year will be allocated between the five research councils.

The total available for the science budget has been known since last month (see Nature 24 November, p.304). Within this total, Sir Keith had very little room to manoeuvre without bringing down on himself the wrath of one or other of the councils, and the results of the exercises are broadly as foreseen a year ago in a forward plan published by the Advisory Board for the Research Councils.

The lion's share of the science budget goes to the Science and Engineering Research Council (SERC), which is scheduled to receive $£ 278$ million next year. This total includes $£ 6$ million intended to help SERC meet the cost of its obligations in subscriptions to international organizations (mainly the European Organization for Nuclear Research), rather less than the $£ 10$ million or so that SERC reckons it is lacking on this score. But negotiations on future allowances for subscription costs are continuing and SERC hopes that an annual sum will in future be reserved for the purpose. The Medical Research Council will receive $£ 119$ million, a slight reduction on what had been expected, and the Social Science Research Council is to be drip-fed on $£ 22$ million. In the middle league are the Agricultural and Food Research Council (AFRC) and the Natural Environment Research Council (NERC), which will receive $£ 46.5$ million and $£ 65.0$ million respectively. NERC last year received an unexpected boost in the form of special support for research in the Antarctic, and this is to continue next year. But neither NERC nor AFRC will receive any significant special allowances for the costs of their enforced restructuring. Like AFRC (see p.725), NERC will now have to face up to a drastic realignment of its research priorities. Dr K. Aldred, the council's finance officer, says that it is impossible to put a figure on the cost of restructuring that the council faces, because many proposals are dependent on the level of support allowed.
Biotechnology Celltech loses
its MRC deal

BRITAIN'S government-backed biotechnology company, Celltech, is to lose its broad right of first refusal on the development of Medical Research Council (MRC) discoveries in recombinant DNA and cell hybridization - a right it has enjoyed for three years under what was originally a five-year agreement. The only rights it will retain will be in areas where collaborative research is already under way, or in a slightly broader area where Celltech already has plans to commercialize an MRC result.

In effect, this may restrict Celltech's rights almost entirely to hybridomas, which certainly puts the young company in a more bracing commercial environment. But, said chief executive Gerald Fairtlough on Monday, Celltech "has never taken anything for granted". Although "it wasn't planned" when Celltech was established that it might lose its exclusive rights, it was "a perfectly natural evolution',. Moreover Celltech was gaining another five-year agreement with the research council, albeit on more restrictive terms. The new agreement, says Fairtlough, also specifies that while Celltech will have no general rights in recombinant DNA and cell hybridization, there will be "a general intent to work together'". The existence of a framework of agreement over patent rights will also aid collaboration, Fairtlough believes.

Does the MRC now intend to hawk some of its research around competing companies? Fairtlough does not know or will not say. Others may have been inhibited in approaching MRC by the Celltech link, he admits. "But I hope we have done and will continue to do a good job for them."

Robert Walgate

- Meanwhile in France the Marseillesbased Immunotech announced last week the opening of new laboratories to house its 16 postdoctoral scientists and 12 technicians. Rather like Celltech, Immunotech has first refusal rights on some areas of research of the national medical research council. Immunotech's agreement with INSERM covers immunology, including vaccines, until 1990. The company's laboratories are built right on the doorstep of the largest immunology laboratory in France, jointly established in 1976 by INSERM and the Centre National de la Recherche Scientifique and directed by Professor François Kourilsky. Celltech, although doing business in France, has not yet felt the winds of competition from Immunotech, which like the British company deals with both contract research and product development (it has $\mathbf{3 0}$ monoclonal antibodies on the market). Immunotech is not profitable yet but expects to go into the black in a year or two, says scientific director Michel Delaage. 